\title{
Protests as Bhopal settlement rebounds on government
}

\section{New Delhi}

THE long legal battle between the Indian government and the Union Carbide Corporation (UCC) of the United States came to an end last week when the Indian Supreme Court fixed an amount of $\$ 470$ million as compensation for victims of the Bhopal gas tragedy.

The court last week directed the US company to pay the Indian government $\$ 425$ million and its Indian subsidiary, Union Carbide India Limited (UCIL), the rupee equivalent of the balance of $\$ 45$ million as "final settlement of all claims, rights, and liabilities" arising out of the the night of 2 December 1984, from a pesticide factory designed and built by UCC and operated by the UCIL. Soon after the tragedy, the Indian government took over the rights of its citizens and has been acting as the sole plaintiff in all suits against UCC - first in a New York district court, then in Bhopal and finally in the Supreme Court in New Delhi where the 38-month-long legal battle ended.

Although the verdict has been accepted by the Indian government, it has evoked extreme reactions in the press and in opposition political parties, which allege that the government has mishandled the

\section{IMAGE UNAVAILABLE FOR COPYRIGHT REASONS}

\begin{abstract}
An angry demonstrater pictured outside the Union Carbide plant in Bhopal following the "grossly inadequate" settlement just awarded by the Supreme Court.
\end{abstract}

world's worst industrial disaster. In fixing responsibility for the disaster, the court thereby indirectly exonerated Carbide from the charges of criminal negligence and violation of safety procedures at the pesticide plant.

The total compensation, to be paid before $23 \mathrm{March}$, is less than the $\$ 600$ million said to have been offered by UCC as an out-of-court settlement two years ago, and is about 15 per cent of what the Indian government had initially sought in damages.

The five judges of the constitution bench of the Supreme Court have acted in an unprecedented manner by announcing the compensation even before hearings were complete. The court was hearing arguments relating to interim compensation, so that its verdict on a "final settlement" was a surprise. The Indian government, which has blamed UCC's defective technology for the disaster, and which had sued the company for $\$ 3,300$ million in damages in a Bhopal trial court, apparently accepted the much lower figure to prevent the matter dragging on any longer.

According to official figures, 2,660 people died and between 30,000 and 40,000 were injured by the release of 40 tonnes of toxic methyl-isocyanate gas, on case. One newspaper described the verdict as a "judicial let-down" and alleged that the level of compensation "is grossly inadequate, indeed laughable". Opposition parties, calling the court ruling "a betrayal of victims and a sell-out to the US multinational", have launched nationwide protests. The settlement issue is sure to be used as ammunition against Prime Minister Rajiv Gandhi's Congress party in the general elections next November.

Popular dissatisfaction over the verdict was also evident in Bhopal, where there was a protest march to the governor's office, and in New Delhi, where police had to be called to disperse violent civil rights groups outside the court.

The dust raised by the controversial court ruling will take time to settle, but the government faces the immediate problem of disbursing the money to surviving victims and relatives of those who died. There are 575,000 claimants and only half the claims have so far been scrutinized. India's track record of relief operations during floods or droughts has not been good, and the biggest question is whether the money due from UCC - the largest amount ever handled in a relief operation in India - will reach the victims.

K. S. Jayaraman

\section{Generic drug-makers win telling point}

\section{London}

Generic drug manufacturers in Britain have won the right to market out-of-patent drugs without themselves having to carry out toxicity tests and clinical trials. That is the effect of a decision last week of the law lords, the subcommittee of the House of Lords which functions as the nearest thing in Britain to a supreme court, which decided that information provided in confidence by companies seeking a product licence can also be used by the licensing authority when considering applications to produce generic copies of the drug.

The case turned on efforts by the United States-based pharmaceutical manufacturer Smith Kline and French (SKF) to resist generic copying of its successful antiulcer drug cimetidine (sold in Britain since 1976 as 'Tagamet'). Ironically, this is one of the drugs developed for SKF by last year's Nobel prize-winner Sir James Black.

Full patent protection on the drug expired last year; since then generic drug manufacturers have been seeking licences to produce copies of the drug. A directive from the Council of the European Communities says that a manufacturer can apply for a licence in such circumstances, and without having to carry out its own tests and trials, provided that it can demonstrate that its products are "essentially similar" to one already licensed.

SKF has argued that in order to demonstrate similarity, generic manufacturers must produce the results of tests and trials, and obtained a High Court ruling in its favour in February 1988. But the Appeal Court decided otherwise, whereupon SKF took its case to the House of Lords.

Last week, in their judgement, the law lords accused SKF of trying to "harass and obstruct" the licensing authority in order to prolong patent protection for its drug. But Cyril Beck, managing director of the generic drugs company Harris, says the legal arguments have extended SKF's monopoly on Tagamet by a year. He estimates that SKF sells $£ 5$ million worth of the drug every month.

Christine McGourty

\section{Embryo research}

Paris

Faced with divergent European laws and practices in the use of human embryos for research, the parliament of the Council of Europe has adopted a recommendation to set up an international body to monitor trends in this controversial field.

The council also looks forward to the possibility of formulating more uniform regulations among member nations, in an effort to prevent the emergence of 'genetic havens' in countries within Europe where laws are lax. 